\title{
THE EFFECT OF SODIUM CHLORIDE 0.9\% INFUSION SOLUTION AND RINGER'S SOLUTION ON PARTICLE SIZE OF INTRAVENOUS LIPID EMULSION (INTRALIPID 20\%)
}

\author{
HAKIM BANGUN*, JUMIATY, ANAYANTI ARIANTO \\ Department of Pharmaceutical Technology, Faculty of Pharmacy, Universitas Sumatera Utara, Jl. Tri Dharma No. 5, Pintu 4, Kampus USU \\ Medan 20155, Indonesia. Email: Hakimb17@yahoo.com
}

Received: 13 September 2016, Revised and Accepted: 14 October 2016

\section{ABSTRACT}

Objective: To study the effect of admixing intralipid (IL) with sodium chloride ( $\mathrm{NaCl}$ ) $0.9 \%$ infusion solution or Ringer's solution (RS) on physical stability of IL.

Methods: Incompatibility test was done in two methods of admixture, i.e. in one container (1:1) and through three-way stopcock (1:2). They were observed for $24 \mathrm{hrs}$ on its emulsion type, $\mathrm{pH}$, microscopic observation of lipid globules, and globules size.

Results: The results of admixing IL and electrolyte solution ( $\mathrm{NaCl}$ or $\mathrm{RS}$ ) in one container and through three-way stopcock showed no changes in color and emulsion type $(\mathrm{O} / \mathrm{W})$. Physical stability evaluation results of IL and $\mathrm{NaCl}$ admixture in one container and through three-way stopcock showed that the pH value was 5.1 and 5.2, respectively, and microscopic observation of lipid globules and its size showed coalescence on 24 hrs with size $625.16 \mathrm{~nm}$ (one container) and stable during $24 \mathrm{hrs}$ (three-way stopcock). Physical stability evaluation results of IL and RS admixture in one container and through three-way stopcock showed that the $\mathrm{pH}$ value was 4.9 and 5.1, respectively, and microscopic observation of lipid globules and its size showed coalescence on $12 \mathrm{hrs}$ with size $572.81 \mathrm{~nm}$ (one container) and flocculation on 24 hrs with size $558.12 \mathrm{~nm}$ (three-way stopcock).

Conclusion: Admixing electrolyte solution ( $\mathrm{NaCl}$ or RS) and IL in one container and through three-way stopcock causes the larger globule size of IL.

Keywords: Intralipid 20\%, Sodium chloride 0.9\% infusion solution, Ringer's solution, Physical stability.

(C) 2017 The Authors. Published by Innovare Academic Sciences Pvt Ltd. This is an open access article under the CC BY license (http://creativecommons. org/licenses/by/4. 0/) DOI: http://dx.doi.org/10.22159/ajpcr.2017.v10i1.15169

\section{INTRODUCTION}

Patients in intensive care unit with various and complex conditions receive numerous intravenous (IV) medications. Frequently, the number of IV medication is more than that of venous access lumens for these patients. Therefore, coadministration of IV medications through the same line is done [1]. More than one IV medication increases the risk of incompatibility [2]. However, this situation is poorly understood by health staff [1]. The risks of incompatibility on patients are particulate emboli, tissue irritation, and therapeutic failure [3]. Several researchers have also studied the incompatibility of injection $[4,5]$.

Parenteral nutrition is used when gastrointestinal tracts cannot be accessed and administered depending on patient's condition [6]. Components of parenteral nutrition include amino acid, carbohydrate, lipid, vitamins, trace elements, and electrolyte [7]. Lipid emulsion is important component in parenteral nutrition [8].

Parenteral nutrition solutions are prepared in two forms: 2-in-1 (amino acid and carbohydrate) and 3-in-1 (amino acid, carbohydrate, and lipid) [9]. Advantages of admixing all nutrients in one container provide more convenience for administration, efficient for pharmacy personnel and storage, cheaper, lessen microbe contamination, usage of medical equipment, and monitoring time by nurse [10]. The total parenteral nutrition (3-in-1) that contains lipid tends to cause physical instability with the presence of electrolyte, especially polyvalent cation [11].

Malnutrition continues to be a major health burden in developing countries (for example, Indonesia) and the most important risk factor for illness and death $[12,13]$. Therapy for malnutrition patients is started with treatment or prevention of hypoglycemia, hypothermia, and dehydration. Hypoglycemia is treated with administration of dextrose $10 \%$ infusion solution [14]. Severe malnutrition is also characterized by essential fatty acid deficiency [13] and is treated by IV lipid emulsion [16]. Electrolyte imbalance is treated by administering Darrow's solution, lactated Ringer's solution (RS), and $0.45 \%$ sodium chloride $(\mathrm{NaCl})[14]$.

The previous study by Driscoll et al. [17] was done evaluating the stability of amino acid, glucose, and electrolyte solution admixture with various formulations of lipid emulsion $20 \%$ which was combination of sunflower oil:soybean oil (1:1) (F1); only soybean oil (F2); mixture of soybean oil:middle chain triglyceride (1:1) (F3); and mixture of olive oil:soybean oil (4:1) (F4). F1 and F2 used egg lecithin as emulsifier, but F3 and F4 used egg lecithin and sodium oleate. Preparation of admixture was done aseptically and it was analyzed in room temperature for 5 times in interval of $30 \mathrm{hrs}$. The results showed that all formulas were unstable between 8 and $24 \mathrm{hrs}$, and each admixture showed increment of lipid globules and contained lipid globules which sized $5 \mu \mathrm{m}$. The research by Cocchio et al. [18] was done by admixing IV lipid emulsion with IV medications through Y-site in ratio 1:1 and the results of PFAT5 (proportion of enlarged droplets $>5 \mu \mathrm{m}$ ) were significantly higher.

Stable IV lipid emulsion contains small droplets with size 200-500 nm. Droplet size $\geq 5 \mu \mathrm{m}$ may cause lipid emboli when it enters blood stream [19]. Lipid emboli are occurred on lungs and brain that can cause acute respiratory failure and brain damage, simple anxiety until coma and death [20].

Based on the explanations above, researcher studied the effect of electrolyte solution ( $\mathrm{NaCl}$ or RS) on physical stability of intralipid (IL) such as alteration in particle size. 


\section{MATERIALS AND METHODS}

Materials

IL(Fresenius Kabi, Jakarta, Indonesia), NaCl (PT. Widatra Bhakti, Pasuruan, Indonesia), RS (PT. Widatra Bhakti, Pasuruan, Indonesia), methylene blue, neutral buffer pH 7.01 (Hanna), acid buffer pH 4.01 (Hanna) and distilled water.

\section{Methods}

Admixing in one container

Admixing $\mathrm{NaCl}$ and IL

$\mathrm{NaCl}$ was admixed with IL in ratio $1: 1(12.5: 12.5 \mathrm{ml})$ on room temperature. Then, it was connected with infusion set with flow rate 1 drop/6 seconds, and the admixture result was collected in glass bottle and then its physical stability was evaluated.

Admixing RS and IL

RS was admixed with IL in the same ratio and method as stated for admixing $\mathrm{NaCl}$ and $\mathrm{IL}$ in one container.

\section{Admixing through three-way stopcock}

Admixing $\mathrm{NaCl}$ and IL

IL was admixed with $\mathrm{NaCl}$ through three-way stopcock in ratio 1:2 (12.5:25 ml) on room temperature with $\mathrm{NaCl}$ flow rate was 1 drop/second while IL flow rate was 1 drop/6 seconds. Both infusion sets were connected to three-way stopcock; the admixture result was collected in glass bottle and then its physical stability was evaluated.

Admixing RS and IL

IL was admixed with RS through three-way stopcock with the same ratio and method as stated admixing $\mathrm{NaCl}$ and IL through three-way stopcock. RS flow rate was 2 drops/second.

Physical stability evaluation of $\mathrm{NaCl}$ or $\mathrm{RS}$ and IL admixture in one container or through three-way stopcock

Emulsion type evaluation

A drop of emulsion from admixture result was placed on object glass and then a drop of methylene blue was added. After that, the admixture was homogenized and closed with another object glass.

\section{pH determination}

$\mathrm{pH}$ of admixture was determined using $\mathrm{pH}$ meter.

\section{Visual observation of lipid globules}

Physical appearance evaluation was done within 0, 20, 40, 60 minutes, $3,6,12$ and 24 hrs with the help of a magnifiying glass.

\section{Microscopic observation of lipid globules}

Lipid globules morphology evaluation was done using digital microscope within $0,20,40,60$ minutes, $3,6,12$ and $24 \mathrm{hrs}$.

\section{Lipid globules size observation}

Globules size evaluation was examined using particle size analyzer $\left(\right.$ Vasco $^{\gamma}$ ) within 0,12 , and $24 \mathrm{hrs}$

\section{RESULTS}

Admixing IL and electrolyte solution ( $\mathrm{NaCl}$ or $\mathrm{RS}$ ) in one container IL is a white color emulsion. The results of admixing IL and electrolyte solution ( $\mathrm{NaCl}$ or $\mathrm{RS}$ ) in one container showed no changes in color.

\section{Admixing IL and electrolyte solution ( $\mathrm{NaCl}$ or $\mathrm{RS})$ through three- way stopcock \\ The results of admixing IL and electrolyte solution ( $\mathrm{NaCl}$ or $\mathrm{RS}$ ) through three-way stopcock was emulsion with white color too.}

Physical stability evaluation of $\mathrm{NaCl}$ or RS and IL admixture in one container or through three-way stopcock

\section{Emulsion type evaluation}

As shown in Table 1, it can be observed that admixtures showed no emulsion phase changes during observation time.

\section{pH determination}

As shown in Table 2, it can be observed that $\mathrm{pH}$ of IL reduced when it was admixed with electrolyte solution. One container admixture and calcium-containing admixture (admixture with RS) had lower pH than other admixtures.

\section{Visual and microscopic observation of lipid globules}

Observation of lipid globules microscopically was done after admixture re-dispersed. Fig. 1a shows no enlargement of lipid globules, and it can be concluded that admixture is stable. Admixtures that showed physical instability (coalescence) are shown in Fig. 1b-d, which were marked by enlargement of lipid globules. Fig. 1e shows flocculation.

\section{Lipid globules size observation}

As shown in Table 3, it was shown that IL and admixtures of IL with electrolyte solution ( $\mathrm{NaCl}$ or $\mathrm{RS}$ ) have lipid droplet size $>400 \mathrm{~nm}$ which is included in conventional emulsion [34]. From Table 3, it was shown that $\mathrm{IL}+\mathrm{NaCl}$ in one container $24 \mathrm{hrs}$, IL+RS in one container 12 and $24 \mathrm{hrs}$, and IL+RS through three-way stopcock 12 and $24 \mathrm{hrs}$ showed instability due to lipid globules size >500 nm [27].

As shown in Table 3, it can be observed that one container admixtures showed larger lipid globules size than that of admixing through threeway stopcock and also lipid globules size increased on admixture that contained RS. The longer the time after admixing, the larger the lipid globules size. This is caused by due to the longer contact time of positive ion with negative charge of phospholipid so that more lipid globules will unite become larger globules.

Lipid globules' size distribution of IL and admixtures of IL and electrolyte solution ( $\mathrm{NaCl}$ or $\mathrm{RS}$ ) on $24 \mathrm{hrs}$ is shown in Fig. 2a-e. The

Table 1: Results of emulsion type evaluation

\begin{tabular}{|c|c|c|c|c|c|}
\hline \multirow[t]{2}{*}{ Time } & \multicolumn{5}{|c|}{ Emulsion type } \\
\hline & IL & $\begin{array}{l}\text { IL + NaCl (1:1) one } \\
\text { container }\end{array}$ & $\begin{array}{l}\text { IL + RS }(1: 1) \text { one } \\
\text { container }\end{array}$ & IL + NaCl (1:2) three-way stopcock & IL + RS (1:2) three-way stopcock \\
\hline 0 minute & O/W & $\mathrm{O} / \mathrm{W}$ & o/W & $\mathrm{O} / \mathrm{W}$ & $0 / \mathrm{W}$ \\
\hline 20 minutes & $0 / \mathrm{W}$ & o/W & o/W & $\mathrm{O} / \mathrm{W}$ & o/W \\
\hline 40 minutes & $0 / \mathrm{W}$ & $0 / \mathrm{W}$ & $0 / \mathrm{W}$ & $\mathrm{O} / \mathrm{W}$ & $\mathrm{o} / \mathrm{W}$ \\
\hline 60 minutes & $0 / \mathrm{W}$ & $0 / \mathrm{W}$ & $0 / \mathrm{W}$ & o/W & $0 / \mathrm{W}$ \\
\hline $3 \mathrm{hrs}$ & $0 / \mathrm{W}$ & $0 / \mathrm{W}$ & $0 / \mathrm{W}$ & $\mathrm{O} / \mathrm{W}$ & $0 / \mathrm{W}$ \\
\hline $6 \mathrm{hrs}$ & $0 / \mathrm{W}$ & $0 / \mathrm{W}$ & $0 / \mathrm{W}$ & $\mathrm{O} / \mathrm{W}$ & $0 / \mathrm{W}$ \\
\hline $12 \mathrm{hrs}$ & $\mathrm{O} / \mathrm{W}$ & o/W & o/W & $\mathrm{O} / \mathrm{W}$ & o/W \\
\hline $24 \mathrm{hrs}$ & $0 / \mathrm{W}$ & $\mathrm{O} / \mathrm{W}$ & $\mathrm{O} / \mathrm{W}$ & $0 / \mathrm{W}$ & $\mathrm{o} / \mathrm{W}$ \\
\hline
\end{tabular}

IL: Intralipid, RS: Ringer's solution, NaCl: Sodium chloride 
largest particle distribution is shown in Fig. 2c. which has the longest tail of distribution and the highest intensity peak.

As shown in Table 4, it can be seen that $\mathrm{IL}+\mathrm{NaCl}$ in one container (24 hrs), IL+RS in one container (12 and $24 \mathrm{hrs),} \mathrm{and} \mathrm{IL+RS} \mathrm{through}$ three-way stopcock (12 and $24 \mathrm{hrs)}$ ) showed particle size more than $1 \mu \mathrm{m}$. IL+RS through three-way stopcock ( 12 and $24 \mathrm{hrs}$ ) showed slower enlargement in size. IL showed a little increment of lipid globules size on $24 \mathrm{hrs}$ due to a little alteration of temperature during observation. The temperature may alterate the size of globules. Nevertheless, the observation was not done in controlled room temperature.

Table 2: $\mathrm{pH}$ of $\mathrm{NaCl} 0.9 \%, \mathrm{RS}$, IL, and its admixtures

\begin{tabular}{ll}
\hline Parenteral solutions & $\mathbf{p H}$ \\
\hline $\mathrm{NaCl} 0.9 \%$ & 4.9 \\
$\mathrm{RS}$ & 5.1 \\
$\mathrm{IL}$ & 7 \\
$\mathrm{IL}+\mathrm{NaCl}(1: 1)$ 1 container & 5.1 \\
$\mathrm{IL}+\mathrm{RS}(1: 1)$ 1 container & 4.9 \\
$\mathrm{IL}+\mathrm{NaCl}(1: 2)$ three-way & 5.3 \\
IL+RS (1:2) three-way & 5.1 \\
\hline
\end{tabular}

IL: Intralipid, RS: Ringer's solution, NaCl: Sodium chloride

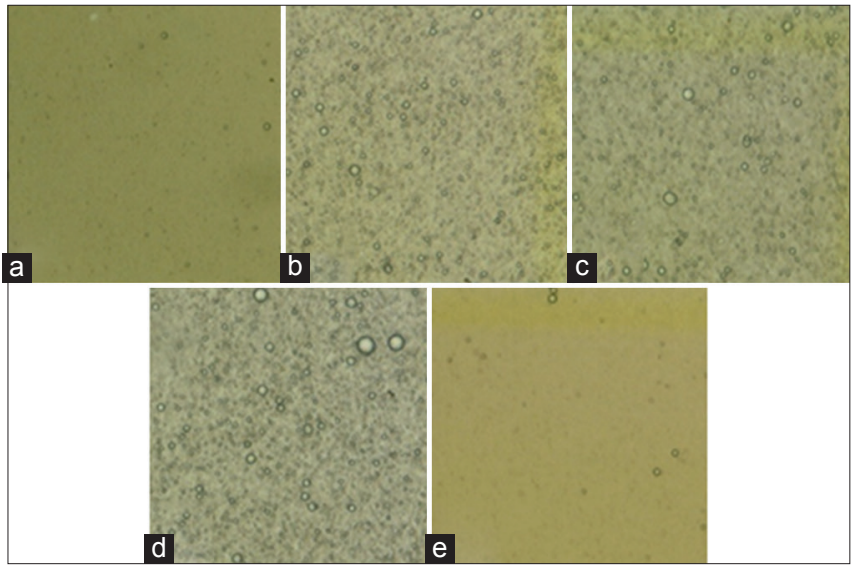

Fig. 1: Microscopic lipid globules observation. (a) Initial; (b) intralipid (IL)+sodium chloride ( $\mathrm{NaCl}$ ) in one container (24 hrs); (c) IL+Ringer's solution (RS) in one container (12 hrs); (d) IL+RS in one container ( $24 \mathrm{hrs);} \mathrm{(e)} \mathrm{IL+RS} \mathrm{through} \mathrm{three-way}$ stopcock (24 hrs)

\section{DISCUSSION}

\section{Emulsion type}

$0 / \mathrm{W}$ emulsion type is usually given parenterally [22] because blood contains blood cell suspension in plasma solution that has lots of water [21] so that $\mathrm{O} / \mathrm{W}$ emulsion type is more soluble in blood fluid and more acceptable to the patient.

Physical appearance showed that during $24 \mathrm{hrs}$, IL which was admixed with electrolyte solution ( $\mathrm{NaCl}$ or $\mathrm{RS}$ ) showed coalescence process. This process did not cause phase inversion because the used emulsifier is dissolved in continuous phase (water) which leads to difficulty occurrence of phase inversion for higher volume ratio (water) [23]. Emulsifier in IL is purified phospholipid which the majority contains nonpolar lecithin. However, if lecithin contacts with water, it is hydrated to form emulsion [24]. In other words, the used emulsifier is soluble in water and inversion phase is difficult to occur.

\section{pH determination}

$\mathrm{pH}$ value of IL was obtained 7 while $\mathrm{pH}$ value that was stated on product label is \pm 8 with the adjustment of $\mathrm{NaOH}$ aqueous solution. This is caused by when IV lipid emulsion was produced before sterilization, and the $\mathrm{pH}$ was adjusted until approximately 8 [25]. Autoclaving process decreases $\mathrm{pH}$ and leads to phospholipid hydrolysis to lysophospholipid and free fatty acid so that this process reduces $\mathrm{pH}$ to 7 and this value is still acceptable by body [26] and meets the requirements of IV lipid emulsion $\mathrm{pH}$ in USP [27]. Slightly alkali condition will cause amphoteric characteristics of lecithin to form negative charge so that the surface charge increases. It also forms thicker bilayer phospholipid films which could form smaller droplet size, increase stability, and had favorable effect in plasma clearance. $\mathrm{Na}^{+}$in $\mathrm{NaOH}$ formed sodium soaps with free fatty acids and stabilized the submicron emulsion by acting as auxiliary emulsifiers [28].

$\mathrm{pH}$ value of other admixtures had lower value than IL and the lowest was shown by RS which was admixed with IL in one container, i.e., 4.9. Lower $\mathrm{pH}$ was caused by $\mathrm{pH}$ of $\mathrm{NaCl}$ and $\mathrm{RS}$ itself was low so admixture of IL with $\mathrm{NaCl}$ or RS would definitely have lower $\mathrm{pH}$. Lower $\mathrm{pH}(<5)$ must be avoided because electrostatic repulsive force among lipid globules lessen and causes globules size enlargement and coalescence [25].

Monovalent cations $\left(\mathrm{Na}^{+}\right.$and $\left.\mathrm{K}^{+}\right)$bind with phosphate groups from phosphatidylcholine and reduce zeta potential of emulsion. Multivalent cation $\left(\mathrm{Ca}^{2+}\right)$ adsorbs hydrophilic parts of phospholipid molecule and reduces zeta potential. Zeta potential becomes smaller with the increasing electrolyte concentration as a result of shrinkage of the electrical double layer at high ionic strength [29]. Based on Debye-Hückel equation, ionic strength of RS (0.158) is higher than $\mathrm{NaCl}(0.154)$ [30].

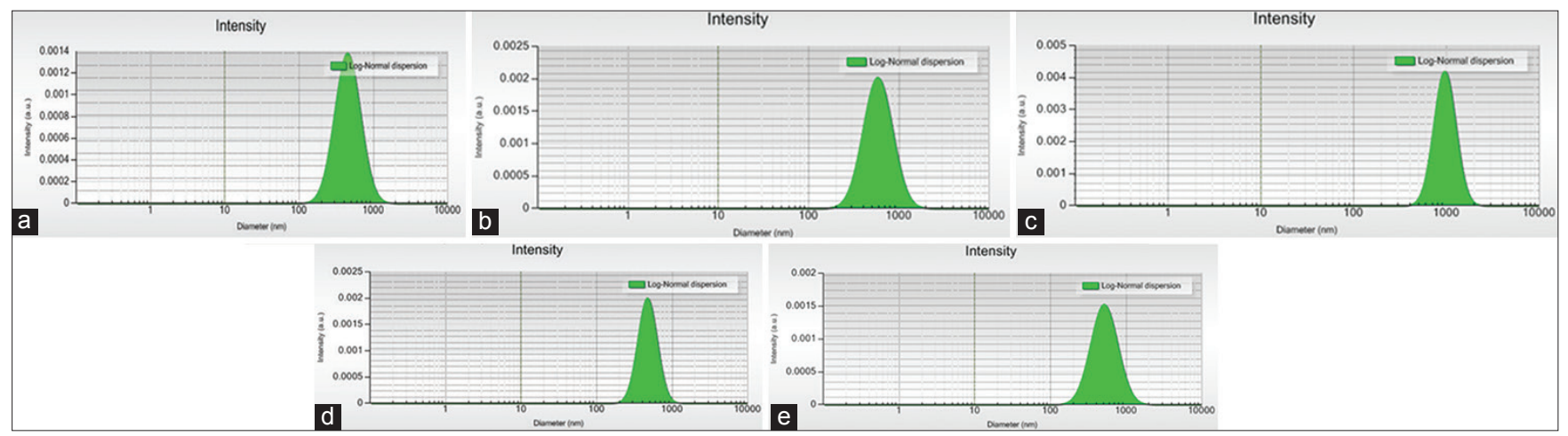

Fig. 2: (a) Lipid globules size distribution of Intralipid (IL) (24 hrs). (b) Lipid globules size distribution of IL which was mixed with sodium chloride ( $\mathrm{NaCl}$ ) in one container ( $24 \mathrm{hrs}$ ). (c) Lipid globules size distribution of IL which was mixed with Ringer's solution (RS) in one container (24 hrs). (d) Lipid globules size distribution of IL which was mixed with NaCl through three-way stopcock (24 hrs). (e) Lipid globules size distribution of IL which was mixed with RS through three-way stopcock $(24 \mathrm{hrs})$ 
Table 3: Results of admixture lipid globules size

\begin{tabular}{llllll}
\hline \multirow{2}{*}{ Time (hrs) } & \multicolumn{4}{l}{ Lipid globules size (D mean intensity) (nm) } \\
\cline { 2 - 6 } & IL & $\begin{array}{l}\text { IL+NaCl (1:1) one } \\
\text { container }\end{array}$ & $\begin{array}{l}\text { IL+RS (1:1) one } \\
\text { container }\end{array}$ & IL+NaCl (1:2) three-way stopcock & IL+RS (1:2) three-way stopcock \\
\hline 0 & 447.16 & 450.73 & 457.54 & 445.99 & 440.56 \\
12 & 457.33 & 475.12 & 572.81 & 471.51 & 539.56 \\
24 & 485.11 & 625.16 & 992.37 & 490.89 & 558.12 \\
\hline
\end{tabular}

IL: Intralipid, RS: Ringer's solution, NaCl: Sodium chloride

Table 4: Results of admixture lipid globules size range

\begin{tabular}{|c|c|c|c|c|c|}
\hline \multirow[t]{2}{*}{ Time (hrs) } & \multicolumn{5}{|c|}{ Admixture lipid globules size range (nm) } \\
\hline & IL & $\begin{array}{l}\text { IL+NaCl }(1: 1) \text { one } \\
\text { container }\end{array}$ & $\begin{array}{l}\text { IL+RS }(1: 1) \text { one } \\
\text { container }\end{array}$ & IL+NaCl (1:2) three-way stopcock & IL+RS (1:2) three-way stopcock \\
\hline 0 & $186.26-891.49$ & 177.88-891.49 & 195.04-933.5 & 195.04-891.49 & 195.04-891.49 \\
\hline 12 & 204.23-891.49 & 234.49-891.49 & 233.49-1230.59 & 204.23-933.5 & 223.93-1122.32 \\
\hline 24 & 195.04-1023.56 & 269.22-1288.59 & 537.17-1778.75 & 245.54-891.49 & 223.93-1175.21 \\
\hline
\end{tabular}

IL: Intralipid, RS: Ringer's solution, $\mathrm{NaCl}$ : Sodium chloride

\section{Visual and microscopic observation of lipid globules}

Largest lipid globules microscopically are shown in Fig. 1d due to admixtures of IL and RS in one container. RS contains divalent ion $\left(\mathrm{Ca}^{2+}\right)$ which is more disruptive than monovalent ions $\left(\mathrm{Na}^{+}\right.$and dan $\left.\mathrm{K}^{+}\right)$[32]. Electrolyte with divalent charge $\left(\mathrm{Ca}^{2+}\right)$ bonds strongly with lipid droplet that is stabilized with lecithin to form ion-lipid complex 1:2 so that it forms positive charge [30]. Lipid globules enlargement is caused by coalescence process that can be seen on its physical appearance. Coalescence occurs when lipid droplet was close, thin layer of water between two close droplets ruptures and causes oil from two droplets combine to form larger droplets [33]. Admixtures of IL and $\mathrm{NaCl}$ also showed enlargement of lipid globules although it was not as high as admixtures with RS

IL and electrolyte solution ( $\mathrm{NaCl}$ or RS) admixture through threeway stopcock achieves more stable condition than admixture in one container as shown in Fig. 1e (flocculation phenomenon) due to the fact that interaction time of both solutions is in shorter time and lots amount of electrolyte solution have been flowed and the remained will interact with lipid globules of IL. Flocculation happens when oil suspended droplet collides due to naturally Brownian motion or agitation. Because of some collisions, attractive force (Van der Waals interaction) occurs between lipid globules because its surface has flaw so that attractive force exceeds repulsion force and causes droplet close to one another [33].

\section{Lipid globules size observation}

Lipid globules size for admixtures that contain RS showed larger globules size. This is due to $\mathrm{Ca}^{2+}$ in $\mathrm{RS}$ which reduces or neutralizes negative charge of phospholipid so that repulsive force decreases between particles and lipid globules coalescence [35].

Human's blood vessel includes aorta, artery, capillary, venule, vena, and vena cava. Smallest human's blood vessel is $5 \mu \mathrm{m}$. Therefore, if the size of lipid globules is $5 \mu \mathrm{m}$ or more, it can cause capillary blockage [36]. Safe IV lipid emulsion should have globules size which is lower than $1 \mu \mathrm{m}$. Globules size $>1 \mu \mathrm{m}$ will turn emulsion instable and has potential to enlarge above $5 \mu \mathrm{m}$ and leads to fat embolism, emboli in capillary and traps on lung capillary so that it affects respiratory function [35,37].

\section{CONCLUSION}

Admixing electrolyte solution ( $\mathrm{NaCl}$ or $\mathrm{RS}$ ) and IL in one container or through three-way stopcock causes the larger globule size of IL but admixing in one container causes larger lipid globule size. Furthermore, $\mathrm{RS}$ is stronger than $\mathrm{NaCl}$ in enlarging lipid globule size.

\section{ACKNOWLEDGMENT}

We would like to thank the Physical Pharmacy Laboratory staffs, Faculty of Pharmacy, University of Sumatera Utara for providing equipment for our study.

\section{REFERENCES}

1. Bertsche T, Mayer Y, Stahl R, Hoppe-Tichy T, Encke J, Haefeli WE. Prevention of intravenous drug incompatibilities in an intensive care unit. Am J Health Syst Pharm 2008;65(19):1834-40.

2. Bergman HD. Incompatibilities in large volume parenterals. Drug Intell Clin Pharm 1977;11(6):345-60.

3. Melsungen AG. Drug Incompatibility. Germany: B. Braun; 2011. p. 8.

4. Konda N, Prashanth P, Arvind G, Shah S. Pharmaceutical development and compatibility studies on cytarabine injection. Asian J Pharm Clin Res 2013;6(3):142-5.

5. Pimple S, Maurya $P$, Salunke $K$, Singh R, Gurjar M, Shah M. Formulation development and compatibility study of dexketoprofen injection used in the management of post-operative pain. Int J Pharm Sci Rev Res 2015;30(1):299-305.

6. Ansel HC, Prince SJ. Kalkulasi Farmasetik. Jakarta: EGC; 2004. p. 163.

7. Dietitians Association of Australia. Parenteral Nutrition Manual for Adults in Health Care Facilities. Australia: Dietitians Association of Australia; 2011. p. 9-13.

8. Fell GL, Nandivada P, Gura KM, Puder M. Intravenous lipid emulsions in parenteral nutrition. Adv Nutr 2015;6(5):600-10

9. Gargasz A. Neonatal and pediatric parenteral nutrition. AACN Adv Crit Care 2012;23(4):451-64.

10. Krzywda EA, Andris DA, Edmiston CE, Wallace JR. Parenteral access devices. In: ASPEN, editor. The Science and Practice of Nutrition Support. USA: American Society for Parenteral and Enteral Nutrition; 2001. p. 257

11. Mirković D, Ibrić S, Antunović M. Quality assessment of total parenteral nutrition admixtures by the use of fractional factorial design. Vojnosanit Pregl 2013;70(4):374-9.

12. Müller $\mathrm{O}$, Krawinkel M. Malnutrition and health in developing countries. CMAJ 2005;173(3):279-86.

13. Riskesdas. (2010). Research Report of Basic Health. Jakarta: Health Research and Development Administration. Page 23.

14. WHO. Management of Severe Malnutrition: A Manual for Physicians and Other Senior Health Workers. Geneva: World Health Organization; 1999. p. 1, 7-8.

15. Duerksen D, McCurdy K. Essential fatty acid deficiency in a severely malnourished patient receiving parenteral nutrition. Dig Dis Sci 2005;50(12):2386-8

16. Calder PC, Waitzberg DL, Koletzko B. Intravenous Lipid Emulsions. Germany: S. Karger; 2015. p. 69.

17. Driscoll DF, Giampietro K, Wichelhaus DP, Peterss H, Nehne J, Niemann W, et al. Physicochemical stability assessments of lipid 
emulsions of varying oil composition. Clin Nutr 2001;20(2):151-7.

18. Cocchio C, Geib AJ, Rynn KO. Physiochemical stability of intravenous fat emulsion in combination with medications used for resuscitation. SOJ Pharm Pharm Sci 2014;1(1):1-3.

19. Schuh RS, Bruxel F, Teixera HF. Physicochemical properties of lecithin-based nanoemulsions obtained by spontaneous emulsification or high-pressure homogenization. Quim Nova 2014;37(7):1193-8.

20. Filomeno LT, Carelli CR, Da Silvia NC, De Barros Filho TE, Amatuzzi MM. Fat embolism: A review for current orthopaedics practice. Acta Ortop Bras 2005;13(4):196-208.

21. Brust M, Schaefer C, Doerr R, Pan L, Garcia M, Arratia PE, et al. Rheology of human blood plasma: Viscoelastic versus newtonian behavior. American Physical Society 2013;110(7):1-5.

22. Mestres GM, Nielloud F. Emulsions in health care applications-An overview. J Dispers Sci Technol 2002;23(1-3):419-39.

23. Vaessen GE, Vissachers M, Stein HN. Predicting catastrophic phase inversion on the basis of droplet coalescence kinetics. Am Chem Soc 1996;12(4):875-82.

24. Rowe RC, Sheskey PJ, Quinn ME. Handbook of Pharmaceutical Excipients. $6^{\text {th }}$ ed. USA: Pharmaceutical Press; 2009. p. 385, 499, 501

25. Floyd AG. Top ten considerations in the development of parenteral emulsions. PSTT 1999;2(4):134-43.

26. Zhao N, Liu X, Sun Y, Wang Y, Pu X, Qin Y, et al. Factors affecting particle size of an intravenous fat emulsions. Asian J Pharm Sci 2010;5(4):161-7.
27. USP. The United States Pharmacopeia. $36^{\text {rd }}$ ed. USA: The United States Pharmacopeial Convention; 2012. p. 321-3, 4124-5.

28. Zhao N, Qin Y, Sun Y, Sun J, He Z. Formulation and preparation of a nitrendipine submicron emulsion. Asian J Pharm Sci 2011;6(3-4):151-8.

29. Wiącek AE. Effect of phospholipid and (phospho) lipase modification on interfacial properties of oil/water emulsion. UMCS Chem 2015;52(1):79-109.

30. Martin AN. Martin's Physical Pharmacy and Pharmaceutical Sciences. China: Lippincott Williams \& Wilkins; 2011. p. 420-7.

31. Wermuth CG, Aldous D, Raboisson P, Rognan D. The Practice of Medicinal Chemistry. $4^{\text {th }}$ ed. USA: Elsevier; 2015. p. 716

32. Schroder AM. Total parenteral nutrition - Problems in compatibility and stability. EJHP Pract 2008;14(1):65-7.

33. Baker MT, Naguib M. Propofol: The challenges of formulation. Anesthesiology 2005;103(4):860-76

34. Burgess DJ. Injectable Dispersed Systems. USA: Taylor \& Francis Group; 2005. p. 101, 213, 223, 218-9.

35. Sacks GS. Drug-nutrient considerations in patients receiving parenteral and enteral nutrition. Pract Gastroenterol 2004;19:39-48.

36. Barret KE, Barman SM, Boitano S, Brooks HL. Ganong's Review of Medical Physiology. $23^{\text {rd }}$ ed. USA: The McGraw-Hill Companies, Inc.; 2010. p. 2.

37. Wermuth CG, Aldous D, Raboisson P, Rognan D. The Practice of Medicinal Chemistry. $4^{\text {th }}$ ed. USA: Elsevier; 2015. p. 716 